\title{
Method and algorithm for determining the geographic coordinates of ground objects from an unmanned aerial vehicle
}

\author{
A. V. Parfiryeva, PhD, Tech., Associate Professor, orcid.org/0000-0003-4112-896X \\ O. V. Parfiryevaa, Head of the Training Laboratory Department, orcid.org/0000-0001-7097-8897 \\ A. V. Dushkin a,b, Dr. Sc., Tech., Associate Professor, orcid.org/0000-0002-8078-8971, a_dushkin@mail.ru \\ aMilitary Educational and Scientific Center of the Air Forces - Zhukovskii and Gagarin Air Forces Academy, \\ 54a, Staryh Bolshevikov St., 394064, Voronezh, Russian Federation \\ bNational Research University of Electronic Technology, Shokin Sq., 1, 124498, Moscow, Zelenograd, \\ Russian Federation
}

\begin{abstract}
Introduction: As practice shows, the accuracy of determining the coordinates of objects is influenced by many factors associated with the presence of errors in measuring the angular coordinates of the optical system, the distance to the object and the presence of an inhomogeneous terrain. Purpose: Improving the accuracy of determining the geographic coordinates of ground objects from an unmanned aerial vehicle. Results: A method and an algorithm for determining geographic coordinates based on the use of a digital terrain model and optimization methods have been developed. The accuracy of calculating the coordinates of the object is increased by minimizing the error in measuring the declination angle, azimuth to the target and slant range. To confirm the analytical calculations, a field experiment was carried out with a car on the ground. At a considerable distance, at which the slant range was $900 \mathrm{~m}$, several data freeze frames were taken. As a result of calculations, the geographical coordinates of the car were obtained in two ways (traditional and developed). Ultimately, the accuracy of calculating coordinates using the developed method is 4.8 times higher. Practical relevance: The method and algorithms for information processing proposed in the work will make it possible to create a number of hardware and software solutions for guidance and target designation systems.
\end{abstract}

Keywords - digital image processing, correlation filtering, PID controller, optimization algorithm, optoelectronic system.

For citation: Parfiryev A. V., Parfiryeva O. V., Dushkin A. V. Method and algorithm for determining the geographic coordinates of ground objects from an unmanned aerial vehicle. Informatsionno-upravliaiushchie sistemy [Information and Control Systems], 2021, no. 3, pp. 19-28. doi:10.31799/1684-8853-2021-3-19-28

\section{Introduction}

Robotics and unmanned aircraft are currently some of the most promising areas of research. Unmanned aerial vehicles (UAVs) have become widespread in both the civilian and military segments and perform an increasing range of tasks, which include the following: monitoring the environment and ground objects, extinguishing fires, video filming, delivery of goods, organizing sports, competitions, etc. $[1,2]$. One of the determining factors in the development of unmanned aviation is the growing role of UAVs in organizing aerial reconnaissance and striking targets in conditions of local conflicts and potential conflicts of a global scale in the future $[3,4]$.

Analysis of the experience of the combat use of UAV groups in military conflicts of recent years, in particular, in Syria, Libya and Nagorno-Karabakh in the period 2018-2020 revealed some of the shortcomings of optoelectronic systems (OES). One of the disadvantages of such systems, operating on the basis of inertial sensors, is a large error in determining the coordinates of the location of ground objects for issuing target indications for their destruction, due to the error in determining the angles of declination and azimuth. This disadvantage is associated with the presence of instrumental errors of inertial sensors, the accuracy of their installation in the block of sensing elements and the quality of setting the initial coordinates of the strapdown inertial navigation system (SINS). The main types of error manifestation, which are an additive component of measurement errors: change in the position of zero signals; emission of random components; conversion errors of scale factors $[5,6]$. The multiplicative component is the scale factor error and manifests itself in the nonlinearity of the transformation of physical measurements into output parameters. In this case, the presence of random noise is always observed in the output signals of the sensors [5]. Thus, a constant increase in the total error is achieved during a prolonged UAV flight, which directly affects the calculation of the horizontal distance to a ground object, especially at large distances (over $5 \mathrm{~km}$ ) and at large elevation angles. Another drawback that affects the accuracy of determining geographic coordinates is the error in measuring the slant range to a ground object by a laser rangefinder at large distances. 
There are a sufficient number of methods and methods for determining the coordinates of ground objects from UAVs, but not all of them meet the safety requirements for their use in the conditions of enemy air defense.

1. With the help of digital image processing and a number of auxiliary systems, including satellite radio navigation and inertial [7]. The disadvantage of this method is the need for shooting in nadir and the impossibility of using it at night.

2. Using an OES with a digital image processing unit installed on board an unmanned aerial vehicle [8, 9]. The author of these works uses ideal azimuth and elevation angles as initial data without taking into account the instrumental error in their measurements, which leads to inaccuracies in calculating the geographic coordinates of ground objects, especially at large distances relative to the UAV. Also, the disadvantage of this approach is the impossibility of taking into account the errors in determining the satellite coordinates of the UAV associated with the shift in the coordinates of the satellite or the clock of the receiver and the satellite $[10,11]$.

3. With the use of active and passive radars, the disadvantages of which are the cumbersomeness of the equipment, high cost, limitation in terms of targets and visibility [12-15].

4. Based on the use of laser radiation energy in conjunction with SINS and satellite radio navigation system. The disadvantage of this method is the low degree of sampling in the construction of the terrain and, accordingly, the drift of inertial sensors.

Improving the accuracy of determining geographic coordinates can be achieved in the following ways.

1. The use of expensive high-precision SINS, satellite navigation systems with differential modes, entailing the development of new high-grade optoelectronic systems. In turn, the development of new systems intended for installation on UAVs involves taking into account a number of restrictions on the mass of the payload, dimensions, etc.

2. Using additional information about the terrain (digital elevation model) to refine the coordinates issued by the module for calculating geographic coordinates and motion parameters of the captured object.

\section{Formulation of the problem}

It is required to determine the geographic coordinates of a moving ground object using an OES installed on a UAV (helicopter or aircraft type). The UAV must be in the air at an altitude and distance from the object, which ensures the correct operation of the OES measuring instruments in accordance with their technical characteristics. The ground object should be located in the line of sight of a day or night camera and not be overlapped by other objects. Meteorological conditions in the OES coverage area contribute to the maximum visibility range of a ground object.

A UAV with an OES must include the following necessary equipment: a gyro-stabilized platform; day camera; infrared night camera (wavelength from 7 to $14 \mu \mathrm{m}$ ); laser rangefinder; GLONASS or GPS receiver; onboard computer.

Requirements for OES: viewing angle: $360 \mathrm{de}-$ grees; the presence of digital image stabilization; a gyro-stabilized system based on a gyroscope and an accelerometer of medium accuracy based on microelectromechanical systems (MEMS) with active stabilization to provide a clear image from cameras in motion and during vibrations; the presence of a three-axis magnetic declination sensor; laser radiation wavelength: $0.9 \mu \mathrm{m}$; the wavelength of the received electromagnetic radiation by the infrared camera: 7-14 $\mu \mathrm{m}$; the wavelength of the received electromagnetic radiation by the day camera: $0.5-$ $0.9 \mu \mathrm{m}$; an adjusted system of day and night cameras and a laser rangefinder.

Determining the coordinates of moving ground objects from photographs obtained by a day or night camera with a UAV involves the solution of three particular problems:

1) tracking a ground object by video sequence to determine its center of coordinates in the image coordinate system;

2) development of an automatic tracking system based on a gyro-stabilized platform;

3) development of a method for determining geographic coordinates based on a digital elevation model (DEM).

Let's consider options for solving these problems.

\section{Algorithm for tracking video sequence}

Before tracking an object, it must be detected. Such localization of a ground object can be automatic or manual. Machine learning algorithms based on Convolutional Neural Networks (CNN) can be used for automatic localization. The process of automatic localization in this case can be conditionally divided into several parts: selection of the most effective neural network model; creation of a special data structure; preparation of a training sample; training the model. To work with regional convolutional neural networks, you can use the open source TensorFlow machine learning computer library from Google, where the OpenCV library takes over the main work of capturing images from a camera 
and digital processing. To solve the problem of localizing ground objects in the image with simultaneous classification, the following $\mathrm{CNN}$ topologies can be used: R-CNN, Fast R-CNN, Faster R-CNN, YOLO, SSD, FPN, and RetinaNet [16]. To increase the number of classified objects, the neural network is retrained on the basis of one of the above models. Variants of learning algorithms are described in $[17,18]$. The result of applying the Faster R-CNN model after the training process on a series of aerial photographs of aircraft and helicopters is shown in Fig. 1.

The bottom line is pretty good. However, in addition to expensive and energy-consuming equipment, neural network approaches have the following serious disadvantages regarding the UAV power supply system.

1. Even on modern video cards it is difficult to achieve high performance from networks. For comparison, the YoloV3 classifier network with a relatively simple architecture can produce an image in $50 \mathrm{~ms}$ [19].

2. The object of interest may not be included in the nomenclature of the neural network classifier. It must be retrained on new datasets (dataset), which leads to a decrease in efficiency in decision making.

Due to the fact that the result of the operation of the neural network is not always stable, the object of interest, including when it has a complex shape, may be missed in some frames at different shooting angles. This situation can lead to failures in the system of automatic guidance of the optical axis of the OES camera to a ground object to determine its coordinates. For more stable tracking of a ground object, it is necessary to use other algorithms called optical trackers - ASEF (Average of Synthetic Exact Filters) and MOSSE (Minimum Output Sum of Squared Error), and to search and classify objects in the image, a neural network.

These two algorithms have a lot in common. They differ only in the method of filter averaging and in that MOSSE creates better filters than ASEF [19].

The general view of the MOSSE filter is represented by the expression:

$$
\hat{\mathbf{W}}_{i}^{*}=\frac{A_{i}}{B_{i}}
$$

where

$$
\begin{aligned}
& A_{i}=\eta \sum_{p=1}^{P} \hat{\mathbf{G}}_{p} \odot \hat{\mathbf{F}}^{p^{*}}+(1-\eta) A_{i-1} ; \\
& B_{i}=\eta \sum_{p=1}^{P} \hat{\mathbf{F}}^{p} \odot \hat{\mathbf{F}}^{p^{*}}+(1-\eta) B_{i-1} .
\end{aligned}
$$

Here $A_{i}$ and $B_{i}$ are filter components; $\hat{\mathbf{F}}^{p} \odot \hat{\mathbf{F}}^{p^{*}}$ the energy spectrum of the rectangle from the $p$-th image; $\hat{\mathbf{G}}_{p}$ - frequency matrix of the desired ideal response; $\eta$ - learning rate during tracking; $P$ number of transformations.

Filter (1) is elementwise multiplied by the frequency matrix $\hat{\mathbf{F}}$, obtained from the next frame and preprocessed. Preprocessing includes non-linear transformation of image pixels (logarithm), which will bring too light and too dark areas to the average. View normalization will work best here:

$$
I=\operatorname{sign}(I-127) \sqrt{|I-127|} \text {. }
$$

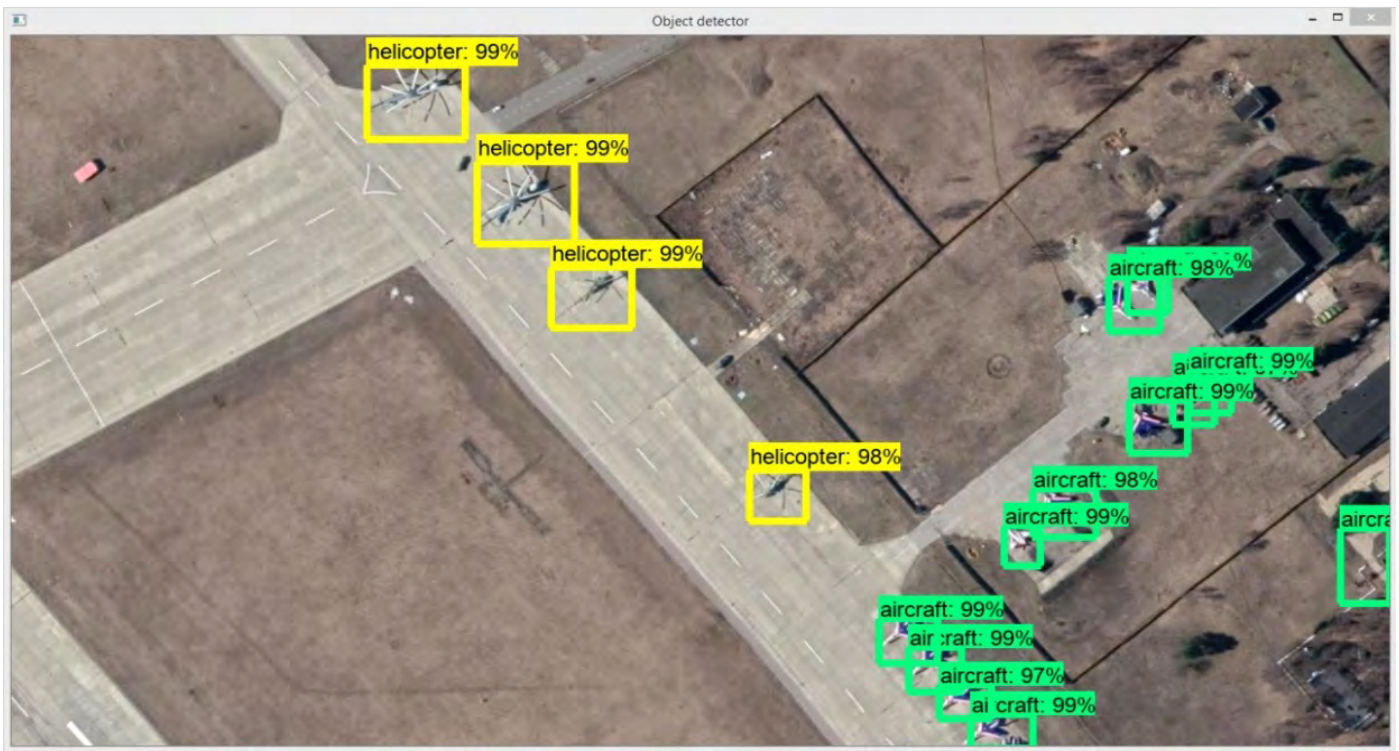

- Fig. 1. The result of the detection and classification of objects in the photograph 
Next, you need to apply the expression:

$$
A=\exp \frac{(x-i)^{2}+(y-j)^{2}}{\sigma^{2}} .
$$

You can also use a 2D Henning window to smoothly zero out the pixel values at the edges of the image. After receiving $\hat{\mathbf{W}}_{i}^{*}$ the response is calculated in the frequency domain:

$$
\hat{\mathbf{G}}_{\text {conv }}=\hat{\mathbf{F}} \odot \hat{\mathbf{W}}^{*} \text {. }
$$

Then the inverse Fourier transform is applied to it to transform it into the spatial domain and the coordinates of the maximum in the resulting $\mathbf{G}_{\text {conv }}$ matrix are found. The coordinates found indicate the new position of the object. The object being tracked may disappear from the frame or be covered by another object. To identify such situations, it is necessary to analyze in more detail the response received from the last frame. To do this, find the maximum $g_{\max }$ of the matrix $\mathbf{G}_{\text {conv }}$, then the $11 \times 11$ square is excluded from the center of this matrix, and the mathematical expectation $\mu_{\mathrm{G}}$ and the standard deviation $\sigma_{\mathbf{G}}$ are calculated from the remaining elements. Calculate the Peak to Sidelobe Ratio (PSR) using the formula

$$
P S R=\frac{g_{\max }-\mu_{\mathbf{G}}}{\sigma_{\mathbf{G}}}
$$

and, if this value is above a certain threshold, then the object is considered detected. The value of this threshold for stable detection is 20 or more. In Fig. 2 shows the data on the frame refresh rate (frames per second) for various filter sizes, due to the increase in the computational load on the on-board computer processor. The software implementation of the presented optical tracker MOSSE is presented in [20]. Application of this approach allows obtaining initial data that can be interpreted into control signals of an automatic control system (ACS) by a

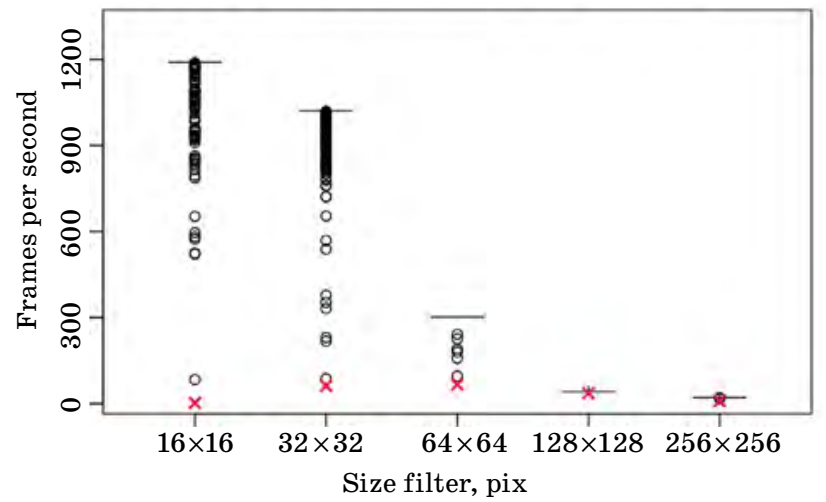

- Fig. 2. Frame refresh rate (fps) for different filter sizes gyro-stabilized UAV platform for aligning the line of sight of the optical system with the direction to the tracked ground object.

\section{Automatic tracking system based on a gyro- stabilized platform}

The alignment of the line of sight of the OES camera is carried out by changing two angular coordinates - pitch and yaw. On board the UAV, as a rule, there is already a gyro-stabilized platform with a controller. The controller is a computer with many digital inputs and outputs for external control, reading signals from inertial sensors, issuing control signals for brushless motors, current state and operating mode. We will consider the implementation of the control method using the example of the BaseCam SimpleBGC 32-bit controller with an open programming interface for building external control modules. For data exchange, the controller provides control and serial interfaces UART and I2C, as well as digital outputs, working on receiving a pulse-width modulation (PWM) signal to control the angular coordinates of the platform. To organize platform control in order to align the line of sight with the direction to the captured ground object, it is necessary to send a PWM signal to the corresponding inputs of the RC_PITCH and RC_YAW controller. To generate control signals, a Raspberry Pi-based calculator is required. The general diagram of an automatic object tracking device, which includes a three-axis gyro-stabilized platform with a control controller, a video camera (thermal imager), a laser rangefinder, and a Raspberry $\mathrm{Pi}$ platform for image processing and generation of control signals, is shown in Fig. 3.

The signals from the calculator are directly proportional to the deviation of the center of the object from the center of the frame and represent two signals of misalignment in the $x$ and $y$ coordinates. The frame center coordinates are the reference signal. To compensate for mismatch signals, a device and a tracking-type automatic control system have been developed, the functional diagram of which is shown in Fig. 4 and 5.

In Fig. 4 introduced the following designations: $x_{o}(t), y_{o}(t)$ - reference signal, respectively, in the coordinates $x$ and $y ; x_{m}(t), y_{m}(t)$ - the current signal, respectively, along the $x$ and $y$ coordinates; CorDev1, CorDev2 - sequential correcting device, respectively, along the coordinates $x$ (diagram Fig. 5, $a$ ) and $y$ (diagram Fig. 5, b); CtrlDev - control device for converting a PWM signal into voltage; Amp - amplifying device; ExDev1, ExDev2 - actuators (platform motors); CtrlObj - control object (platform with a video camera or thermal imager); 


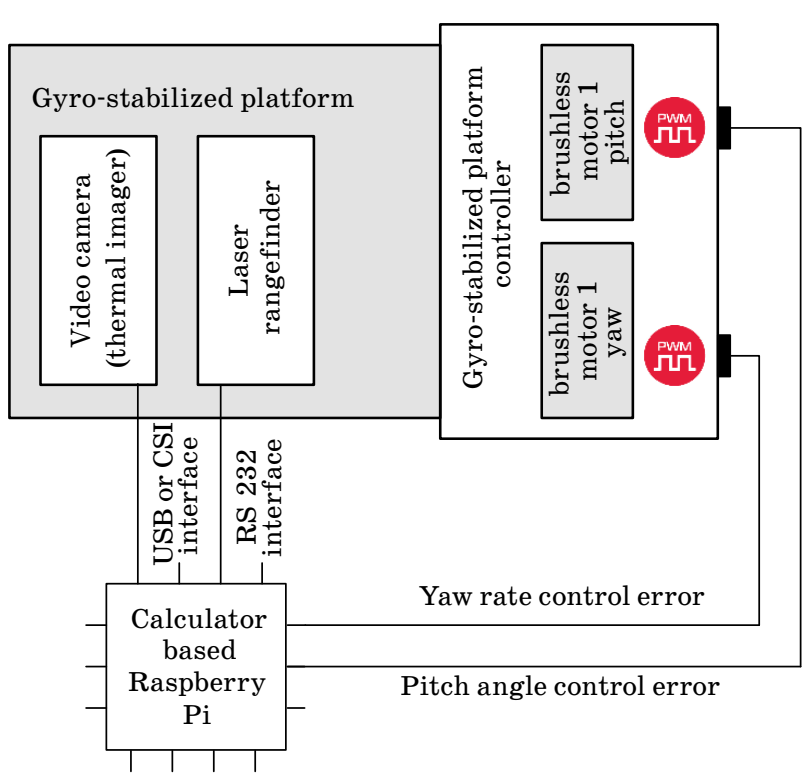

Fig. 3. Diagram of the automatic tracking system of the object and the controller of the gyro-stabilized platform

CompDev is a computing device that issues control signals to the controller of the gyro platform [21].

The purpose of tracking is the most accurate and fast alignment of the line of sight of the camera and the beam of the laser rangefinder with the direc- tion to the object. This is how the correct reading of the initial data is achieved for the implementation of the algorithm for determining the coordinates of ground objects from the UAV using the video stream.

\section{Method for determining geographic coordinates based on digital elevation model}

The solution to the third particular problem is based on the use of DEMs obtained using the methods of classical digital photogrammetry in conjunction with computer vision algorithms. For this, the advanced Agisoft Metashape software was used. Its advantage is that machine learning technologies are used in the analysis and post-processing, which leads to an increase in the accuracy of the results obtained. With the help of Metashape, during image processing, images are converted into dense point clouds, and a digital elevation model is built only from those points of a dense cloud that are classified as points of the earth's relief. A terrain model can be created in the form of an triangular irregular network, in the form of a digital elevation model (DEM), and also as a set of contour lines (isohypsum) records with the required elevation of the relief section. The terrain model in the form of a triangular irregular network has higher resolu-

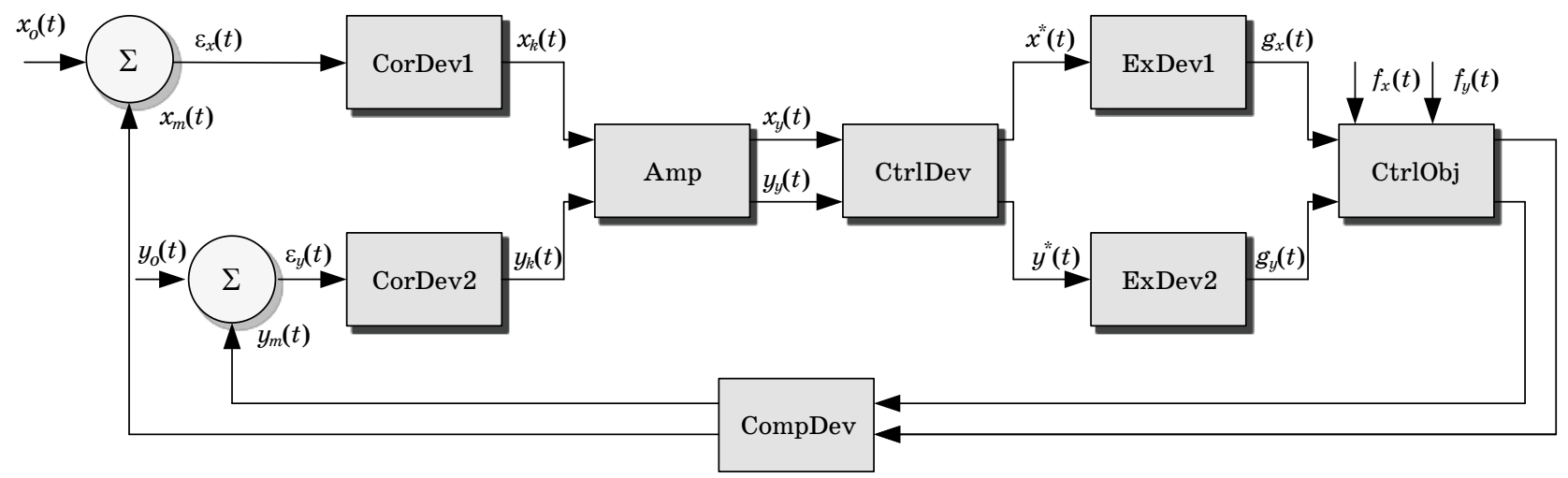

Fig. 4. Functional diagram of the developed tracking type ACS

a)

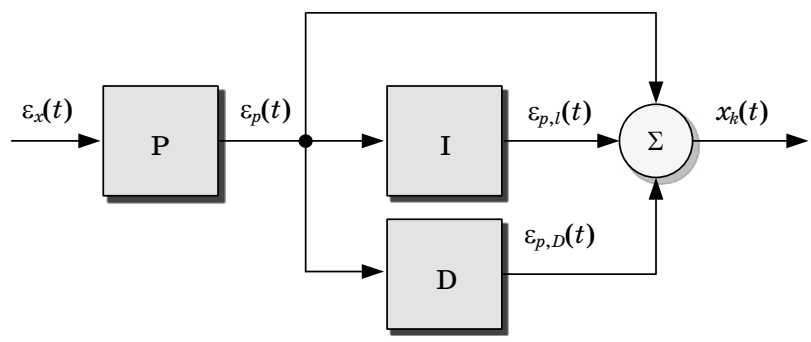

b)

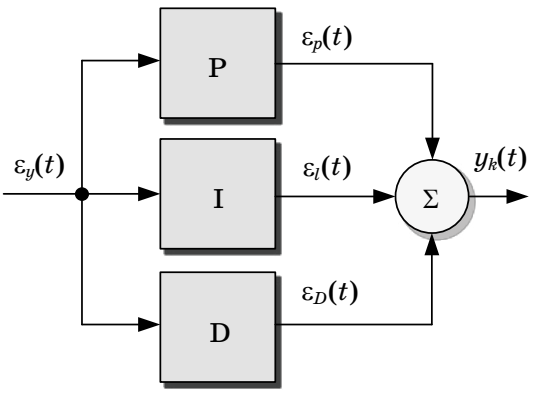

Fig. 5. Functional diagrams of correcting devices based on the PID controller: $a-$ coordinate $x$; $b-$ coordinate $y$ 
tion in areas where the surface is extremely irregular, and lower resolution in areas with a uniform surface. DEM accuracy can reach $16 \mathrm{~cm}$ at a scale of 1:500. The DEM interval (grid step) can reach 0.003 arc seconds $(0.1 \mathrm{~m})$, depending on the technical characteristics of the camera, shooting altitude, weather conditions, etc. A terrain model in the form of a DEM is presented in the following formats: GeoTIFF, Arc / Info ASCII Grid (ASC), Band interlieved (BIL), XYZ or as tiles in the Sputnik KMZ format. The DEM format is accepted by all modern programming languages, including Python. On the Internet, you can find services that allow you to get DEM in one click (for example, Open Aerial Map. https://map.openaerialmap.org/). Fig. 6 is an illustration of this method.

Geographic coordinates are calculated by solving a multiparameter optimization problem based on an optimization algorithm that minimizes the functional of the residual, which is the square of the difference between the height of the object, calculated by the goniometric-rangefinder method $h_{c}$, and the height of the object from the DEM $h *$ :

$$
\begin{gathered}
\Im(\alpha, \beta, d): \min _{\mathfrak{I}}\left\|h_{c}(\alpha, d)-h^{*}\left(x_{0}+L_{x}, y_{0}+L_{y}\right)\right\|_{2} ; \\
\left\{\begin{array}{l}
L_{x}=d \cdot \sin (\alpha) \cdot \sin (\beta) ; \\
L_{y}=d \cdot \sin (\alpha) \cdot \cos (\beta) ; \\
h_{c}=h_{0}-d \cdot \cos (\alpha) .
\end{array}\right.
\end{gathered}
$$

In expression (6): $\alpha, \beta-$ current angles of sight and azimuth to the ground object, obtained from the controller of the UAV's gyro-stabilized platform; $d$ - slant range to a ground object, measured by a laser rangefinder; $L$ is the horizontal range to a ground object; $x_{0}, y_{0}, h_{0}$ - geographic coordinates of the UAV location (latitude, longitude, altitude) obtained using a GLONASS or GPS receiver.

The accuracy of calculating the coordinates of the object is increased by minimizing the error in measuring the angle $\alpha$, azimuth to the ground object $\beta$ and slant range $d$. In accordance with analytical calculations, the error in determining the coordinates of a ground object by the traditional method is within the red zone. The error in deter-
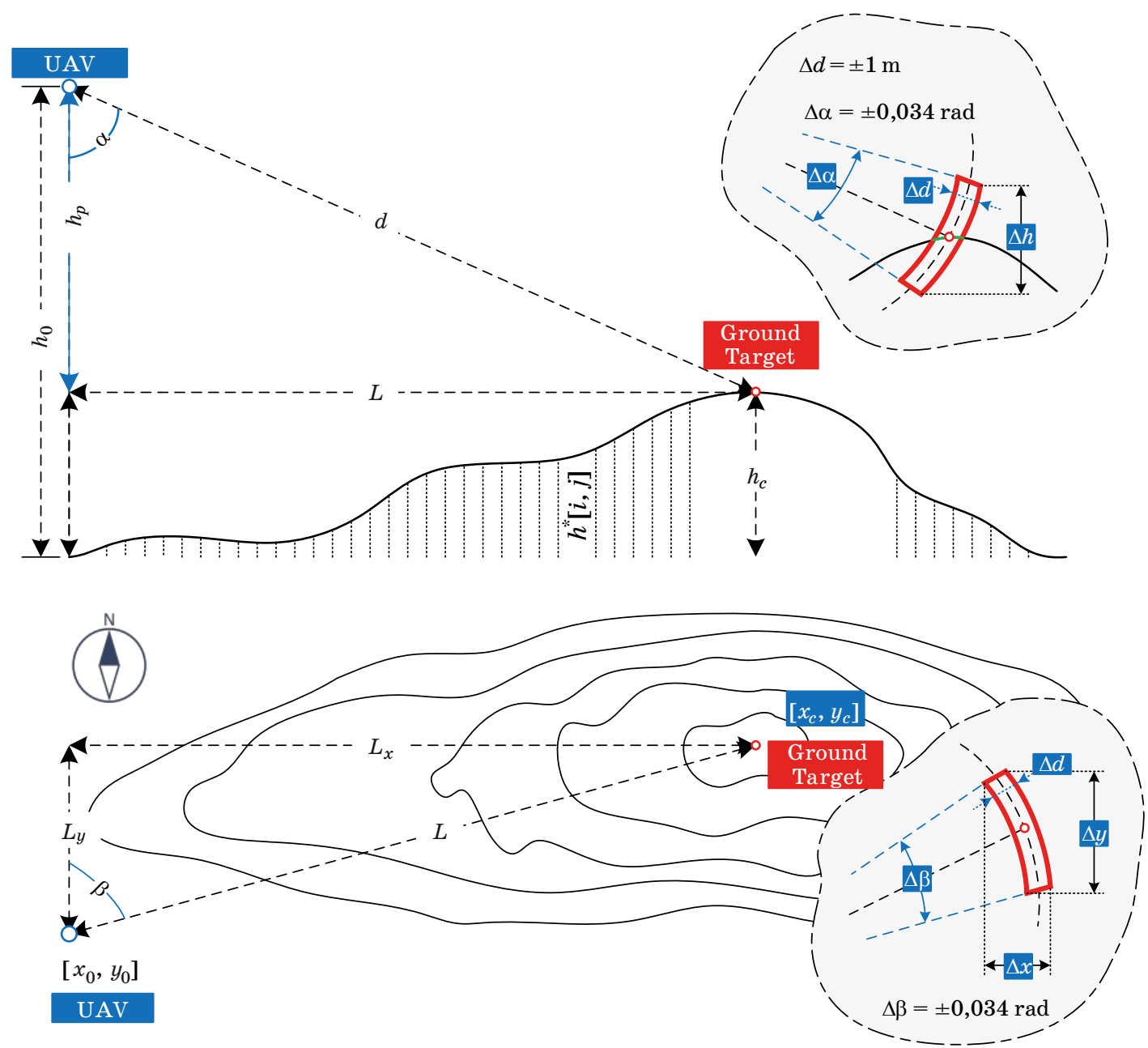

Fig. 6. Illustration of a method for determining the coordinates of ground objects 


\section{ОБРАБОТКА ИНФОРМАШИИ И УПРАВАЕНИЕ}
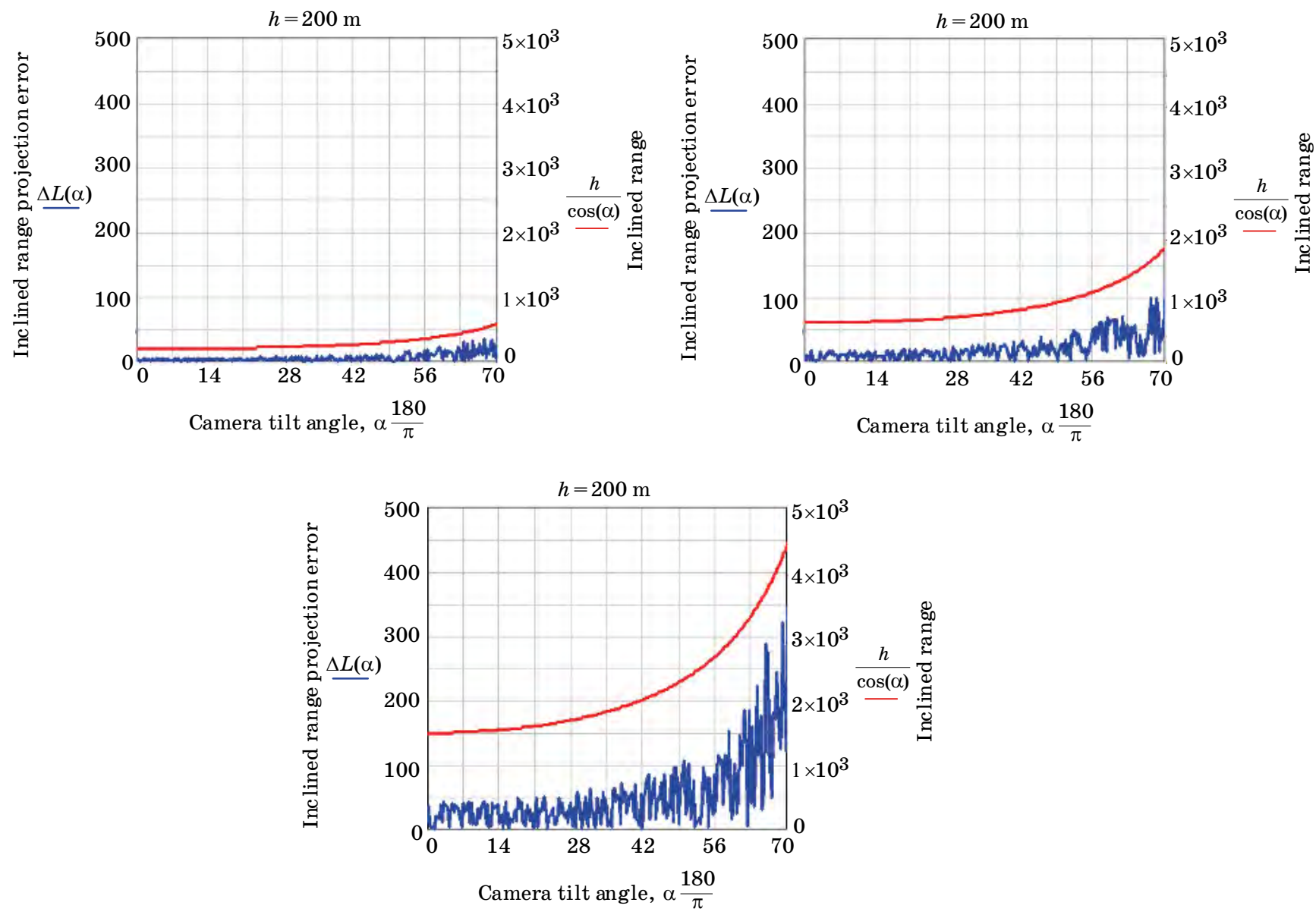

- Fig. 7. Graphs of horizontal range error distribution

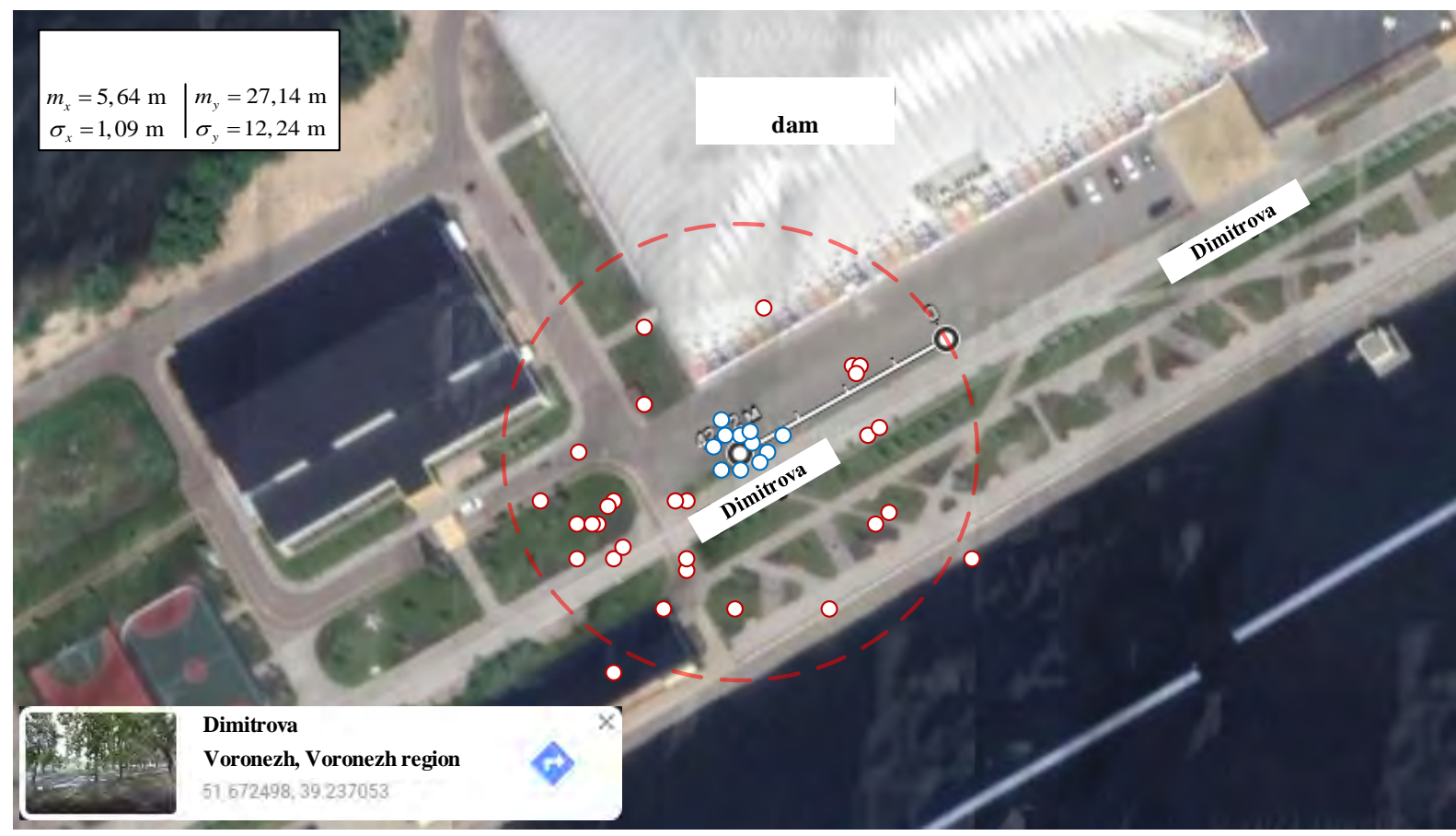

- Fig. 8. Evaluation of the calculation of geographic coordinates in two ways 

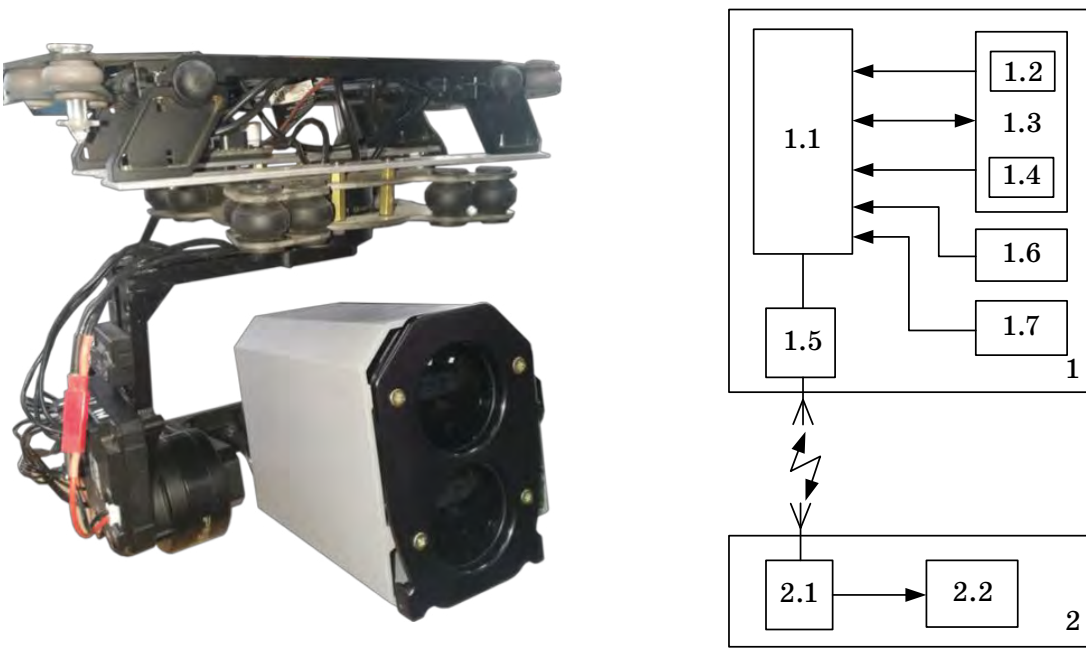

\section{UAV}

1.1. Onboard computer

1.2. CCTV unit

1.3. Gyro-stabilized platform

1.4. Laser rangefinder

1.5. Transceiver

1.6. Satellite receiver with magnetometer

1.7. Barometric altimeter 2. Ground control post

2.1. Transceiver

2.2. Ground control station

2

- Fig. 9. General view of the ECO and its block diagram

mining the coordinates by the developed method lies at the intersection of the red zone with the horizontal surface. The dynamic values of the analytically calculated error in measuring the horizontal range, depending on the angle of sight of the OES and the height of the UAV, are shown in Fig. 7.

To confirm the analytical calculations, an experiment was carried out with a car on the ground. At a considerable distance, at which the slant range was $900 \mathrm{~m}$, several data freeze frames were taken. As a result of calculations, the geographical coordinates of the car were obtained in two ways (traditional red circles and developed - blue circles, Fig. 8).

Ultimately, the accuracy of calculating coordinates by the developed method was increased by 4.8 times. A general view of the OES installed on a drone-type UAV and its block diagram implementing this method is shown in Fig. 9.

\section{Conclusion}

Thus, an algorithm and a method for determining the geographic coordinates of ground objects based on the OES installed on board the UAV have been developed. This makes it possible to more efficiently and accurately calculate the coordinates of any ground object visible in the visible and infrared ranges of the electromagnetic spectrum from the UAV in a time mode close to real. The method is based on an innovative approach to using the DEM obtained using the methods of classical digital photogrammetry in conjunction with modern computer vision algorithms. The degree of discreteness of the DEM, which is achieved by the quality of photographs, the resolution of the camera, the height of the survey, and computational costs, will have a direct impact on the estimation of the calculation of the coordinates of a ground object. The results of the experiment show that the accuracy of calculating the coordinates by the developed method can be increased by 4.8 times in comparison with the traditional goniometric-rangefinder method.

\section{Reference}

1. Kartenichev A. Yu., Panfilova E. V. Fire extinguishing technologies using unmanned aerial vehicles. Pozharnaya bezopasnost': problemy i perspektivy, 2019, no. 10, pp. 149-151 (In Russian).

2. Makarov K. S. Block diagram of a complex with an unmanned aerial vehicle intended for monitoring the territory and objects in conditions of low availability of communication channels. Auditorium, 2019, no. 4(24), pp. 48-53. Available at: https://auditorium. kursksu.ru/\#new-number?id=156 (accessed $20 \mathrm{Janu}-$ ary 2021) (In Russian).

3. Nartov M. V., Polyanin K. S. Weapon system designed to counter unmanned aerial vehicles. Nauka bez granits, 2018, no. 1(18), pp. 48-51 (In Russian).

4. Afonin I. E., Makarenko S. I., Petrov S. V., Privalov A. A. Analysis of the experience of the combat use of groups of unmanned aerial vehicles to defeat anti-aircraft missile systems of the air defense system in military conflicts in Syria, Libya and $\mathrm{Na}^{-}$ gorno-Karabakh. Systems of Control, Communication and Security, 2020, no. 4, pp. 163-191 (In Russian). doi:10.24411/2410-9916-2020-10406

5. Andreyev S. V. Ilinykh V. V., Ilinykh O. A., Chertkov M. S., Klyuchnikov A. V. Estimation of inertial sensors error impacton platformless inertial navigation system accuracy. Journal of "Almaz - Antey" Air and Space Defence Corporation, 2018, no. 2, pp. 29-34. doi:10.38013/2542-0542-2018-2-29-34 
6. Egoshkin N. A. Metody vysokotochnoi geometricheskoi obrabotki informatsii ot sovremennykh sistem kosmicheskogo zondirovaniya Zemli. Dis. dokt. tehn. nauk [Methods for high-precision geometric processing of information from modern space sensing systems of the Earth. Dr. tech. sci. diss.]. Ryazan', RGRTU Publ., 2019. 35 p. (In Russian).

7. Kaplin A. Yu. Sposob opredeleniya koordinat nazemnykh ob»ektov pri fotos»emke s bespilotnogo letatel>nogo apparata [Method for Determining the Coordinates of Ground Objects when Photographing from an Unmanned Aerial Vehicle]. Patent RU, no. RU 2726902, 2020.

8. Shipko V. V., Rubinov V. I., Sharonov I. E., Khanov A. S. Algorithm for determining the coordinates and parameters of the movement of ground objects. Vestnik VGTU, 2018, no. 1, pp. 43-48 (In Russian).

9. Shipko V. V. On some features of determining the coordinates of moving surface targets by the opto-electronic system of an unmanned aerial vehicle of the "multicopter" type. Vozdushno-kosmicheskie sily. Teoriya i praktika, 2019, no. 12, pp. 252-261 (In Russian).

10. Makarenkov A. Modular transfer function compensation for hyperspectral data from Resurs-P satellite system. Image and Signal Processing for Remote Sensing XXIV, 2018, vol. 10789, pp. 301-307.

11. Egoshkin N. Standard image products of Russian highly elliptical remote sensing system "Arktika-M". Image and Signal Processing for Remote Sensing $X X I V, 2018$, vol. 10789, pp. 430-436.

12. Nasenkov I. G. Sposob opredeleniya uglovykh koordinat tseli s pomoshch〉yu lineinoi antennoi reshetki [Method for determining the angular coordinates of the target using a linear antenna array]. Patent RU, no. RU 2638174, 2017.

13. Smirnova D. M. Obnaruzhenie i izmerenie koordinat dvizhushchikhsya nazemnykh ob»ektov $v$ mnogopozitsionnoi prosvetnoi radiolokatsionnoi sisteme. Dis. kand. tekh. nauk [Detection and measurement of coordinates of moving ground objects in a multi-position transmissive radar system. PhD diss.]. Nizhnii Novgorod, NGTU Publ., 2012. 16 p. (In Russian).
14. Chernodarov A. V. Flight testing of a distributed inertial-satellite micronavigation system for a synthetic aperture radar. Nauchnyi vestnik MGTU GA, 2017, no. 1, pp. 222-231 (In Russian).

15. Bazhenov A. V. The use of unmanned aerial vehicles for radar search of aircraft and ships that have suffered an accident. Sistemy upravleniya, svyazi i bezopasnosti, 2020, no. 2, pp. 212-230 (In Russian).

16. Raspoznavanie ob"ektov $v$ rezhime real'nogo vremeni na iOS s pomoshch'yu YOLOv3 [Real-time Object Recognition on iOS with YOLOv3]. Available at: https:// habr.com/ru/post/460869 (accessed 12 February 2021).

17. Dushkin A. V., Porfiriev A. V., Sumin V. I. Algorithm of measurement information processing for hardware and software complex capture and automatic tracking of unmanned aerial vehicle. Proceedings. 2017 2nd International Ural Conference on Measurements (UralCon). South Ural State University, Chelyabinsk, Russia, 2017, 16-19 Oct, pp. 199-204. doi:10.1109/URALCON.2017.8120710

18. Parfiryev A. V., Dushkin A. V., Dubrovin A. S., Stepanov L. V. Control of unmanned aerial vehicles based on the detection algorithm. Journal of Physics: Conf. Series 1202 (2019) 012014. doi:10.1088/17426596/1202/1/012014

19. Optical trackers: $A S E F$ and MOSSE. Available at: https://sudonull.com/post/12040-Optical-trackersASEF-and-MOSSE (accessed 20 January 2021).

20. Parfiryev A. V., Ischuk I. N., Dushkin A. V. Algorithm for controlling the trajectory of an unmanned aerial vehicle with the possibility of flying around obstacles. 2020 IEEE Conference of Russian Young Researchers in Electrical and Electronic Engineering (EIConRus 2020), Moscow, Russia, 2020, 27-30 Jan, pp. 23952400. doi:10.1109/EIConRus49466.2020.9039467

21. Parfiryev A. V., Dushkin A. V. The software implementation of the system of automatic observation of ground objects based on correlation analysis. 2019 IEEE Conference of Russian Young Researchers in Electrical and Electronic Engineering (EIConRus 2019), Moscow, Russia, 2019, 28-31 Jan, pp. 1749-1753. doi:10.1109/EIConRus.2019.8656636 
УДК $623.1 / .7$

doi:10.31799/1684-8853-2021-3-19-28

Способ и алгоритм определения географических координат наземных объектов с беспилотного летательного аппарата

А. В. Парфирьев ${ }^{\mathrm{a}}$, канд. техн. наук, доцент, orcid.org/0000-0003-4112-896X

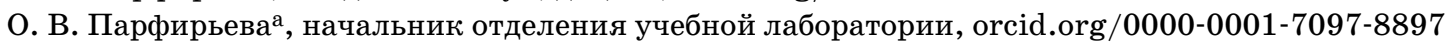

А. В. Душкин

аВоенный учебно-научный центр Военно-воздушных сил «Военно-воздушная академия им. профессора

Н. Е. Жуковского и Ю. А. Гагарина», Старых Большевиков ул., 54а, Воронеж, 394064, РФ

бНациональный исследовательский университет «Московский институт электронной техники», Шокина пл., 1 , Москва, Зеленоград, 124498, РФ

Введение: как показывает практика, на точность определения координат наземных объектов летательными аппаратами с помощью оптических приборов влияет множество факторов, связанных с погрешностями в измерении угловых координат оптической системы, дальности до объекта и наличием неоднородного рельефа местности. Цель: разработка алгоритма повышения эффективности и точности определения географических координат наземных объектов с беспилотного летательного аппарата. Результаты: разработаны способ и алгоритм определения географических координат, основанный на применении цифровой модели рельефа местности и методов оптимизации. Точность расчета координат объекта повышается за счет минимизации ошибки измерения угла склонения, азимута на наземный объект и наклонной дальности. Для подтверждения аналитических расчетов проведен натурный эксперимент с автомобилем на местности. На значительном расстоянии, при котором наклонная дальность составила 900 м, произведено несколько стоп-кадров данных. В результате расчетов получены географические координаты автомобиля двумя способами - традиционным и разработанным. В конечном итоге точность расчета координат разработанным способом в 4,8 раза выше. Практическая значимость: предложенный в работе способ и алгоритмы обработки информации позволяют создать ряд аппаратных и программных решений для систем наведения и целеуказания.

Ключевые слова - цифровая обработка изображений, корреляционная фильтрация, ПИД-регулятор, оптимизационный алгоритм, оптико-электронная система.

Для цитирования: Parfiryev A. V., Parfiryeva O. V., Dushkin A. V. Method and algorithm for determining the geographic coordinates of ground objects from an unmanned aerial vehicle. Инфорлационно-управляющие системы, 2021, № 3, c. 19-28. doi:10.31799/16848853-2021-3-19-28

For citation: Parfiryev A. V., Parfiryeva O. V., Dushkin A. V. Method and algorithm for determining the geographic coordinates of ground objects from an unmanned aerial vehicle. Informatsionno-upravliaiushchie sistemy [Information and Control Systems], 2021, no. 3, pp. 19-28. doi:10.31799/1684-8853-2021-3-19-28

\section{ПАМЯТКА АМЯ АВТОРОВ}

Поступающие в редакиию статьи проходят обязательное рецензирование.

При наличии положительной рецензии статья рассматривается редакционной коллегией. Принятая в печать статья направляется автору для согласования редакторских правок. После согласования автор представляет в редакцию окончательный вариант текста статьи.

Процедуры согласования текста статьи могут осуществляться как непосредственно в редакции, так и по е-mail (ius.spb@gmail.com).

При отклонении статьи редакция представляет автору мотивированное заключение и рецензию, при необходимости доработать статью - рецензию.

Редакция журнала наполинает, что ответственность за достоверность и точность реклалных материалов несут реклалодатели. 